\title{
The Importance of Corporate Social Sustainability in the Anti-Crisis Management of a Hotel Business
}

\author{
Irina Ovchinnikova*, Elena Davydova, Tatiana Volovik, Irina Vashliaeva \\ Ural State University of Economics, Ekaterinburg, Russia \\ ${ }^{*}$ Corresponding author.Email: manager@prikamie-hotel.ru
}

\begin{abstract}
The relevance of the study is due to the need to formulate anti-crisis measures in the context of the coronavirus crisis and the development of a new technological stage of Industry 4.0. The analysis of the main trends in corporate sustainability and the results of the research carried out (Hh.ru research was used) of the labor market indicate that it is necessary to make changes in the personnel management system, both at the methodological level and in practice, in accordance with the interests of stakeholders. The problems of corporate social sustainability will negatively affect the implementation of anti-crisis management in hotel businesses, in connection with which the need for new personnel management tools is determined.
\end{abstract}

Keywords: hotel sector, crisis management, corporate sustainability.

\section{INTRODUCTION}

Ensuring corporate sustainability of hotel businesses is one of the tasks of managers in modern conditions. The UNWTO calls for such priority areas in hotel activities. The Global Sustainable Tourism Council (GSTC), the body that regulates global standards for sustainable business in the travel industry, has proposed a system of indicators for hotels [1]. The purpose of developing such indicators is to provide a uniform approach to understanding "sustainable development in tourism". These criteria include: sustainable management; society; economy; culture; ecology [2].

In turn, many foreign and Russian researchers were engaged in the study of corporate sustainability: J. Elkington [3], R. Steuer [4], G. S. Rosenberg [5], etc. Taking into account the peculiarities of hotel services and the importance of balancing the interests of all stakeholders, the meaning of corporate sustainability most fully reflects the definition proposed by T. Dillick and K. Hawkerst: "the satisfaction of direct and indirect stakeholders of the company (such as shareholders, employees, consumers, local communities, etc. etc.) that do not conflict with the needs of future generations of stakeholders. They also define social sustainability as one of the criteria and imply by it the company's activities to increase human and social capital [6].

According to the GSTC, the following criteria are defined for accommodation facilities in order to maximize socio-economic benefits for the local community [7]:

1. providing equal opportunities for employment and career advancement, including for leadership positions;

2. respect for labor rights, ensuring a safe working environment (the level of wages is monitored and regularly reviewed in accordance with the national standards of the subsistence level; working conditions in accordance with the observance of sanitary and hygienic standards); employees are offered regular training, experience and career opportunities.

According to J. Elkington, during the formation of a new paradigm of corporate sustainability, corporate governance is shifting from exclusive to inclusive development, and the values of companies and employees that were previously constant are now undergoing changes [3]. Thus, we can say that in the hotel industry there is a desire to actively search for new approaches to balance the interests of stakeholders and determine their values, ensuring the growth of the value of the hotel product itself. This became especially relevant for all stakeholders in the crisis pandemic and post-pandemic economy, and in the conditions of the formation of Industry 4.0. 


\section{METHODS}

In the course of the work, the methods of general scientific research were used: analysis and synthesis, literary-analytical, statistical.

Analysis of the hotel market allows us to determine the following features of its development:

- firstly, the penetration of digital technologies into the activities of hotel businesses;

- secondly, the change in business processes due to the use of new technologies;

- thirdly, the new generation born after 2000 is already becoming an active consumer of hotel services. In 2019 , it was $32 \%$ of the world's population. As a result, a change in the hotel product for new needs: digitalization of the product, greening, speed of service, an individual approach, an emotional component in the consumption of a hotel product;

- fourthly, the personnel problem. During the last global crisis, UNWTO drew attention to the fact that the hospitality sector has been hit hard since March 2020, and 120 million jobs are still under threat. Job creation fell $72 \%$ in 2020 compared to 2019 (fDi Financial Times, 2020) [8]. This decline was due to travel restrictions around the world, which resulted in the loss of 1 billion international tourists. Now it is necessary to think about the issues of training professionals and employment of the labor force.

\section{RESULTS}

One of the main problems of corporate governance in a crisis is the formation of a new model of the personnel management system, which will help in the implementation of corporate social sustainability of enterprises and provide an effective anti-crisis strategy.

It is necessary to determine the main factors affecting the current and future personnel management system:

- development of an individual approach to employees;

- delegation of authority and development of the creative potential of employees;

— creation of favorable conditions for employment;

— increasing the overall involvement and satisfaction of all business participants.

For a faster and more effective overcoming of the consequences of the impact of the crisis, as well as to maintain a competitive position, it is necessary to apply methods of quick adaptation to current conditions, taking into account the importance of developing corporate social sustainability.
1) The development of an individual approach to employees is due to the fact that the hotel service directly depends on the emotional state of the staff. In the context of an unstable external environment, it is important to revise the applied styles to personnel management. Carlson Rezidor Hotel Group, Inter Continental Hotels Group (IHG), Marriott and other hotel operators are already implementing the concept of corporate sustainability and, in addition to caring for the environment, developing social projects, great attention is paid to employees: training in emotional intelligence, creating their educational schools for the development of young specialists and assistance in career growth, cooperation with educational institutions for training, etc. Leading international educational institutions are introducing the Human Capital and Development specialization into their hospitality programs (Swiss Education Group). Not only in the hotel business, new ways of working with personnel are being implemented, so the Beeline company introduces new motivational programs, conducts training at its university ( 20.6 hours of training per year for each employee), etc. In a pandemic year, they increased spending on life and health insurance, introduced programs of psychological and social well-being, consultations with an in-house psychologist, etc.

Thus, it is worth making an assumption about the ongoing transformation of styles of personnel management.

2) Delegation of authority and development of the creative potential of employees is due to the fact that one of the stakeholders in the concept of corporate social sustainable development is the consumer. An individual approach, satisfaction of his needs, comfort, impressions and emotions becomes important for the modern consumer. It is possible to increase the value of the offer for the consumer through the development of soft skills: communication skills, empathy, the ability to work in a team, creativity, the ability to quickly make decisions on their own.

3) To obtain a better workforce, it is necessary to create conditions for young employees. According to the Hh.ru research conducted in March-April 2020, among 190,025 applicants, including 513 young specialists, answers were provided to two questions (in the research itself, respondents were asked to answer 13 questions) [9]:

1. Index of the well-being of applicants. 


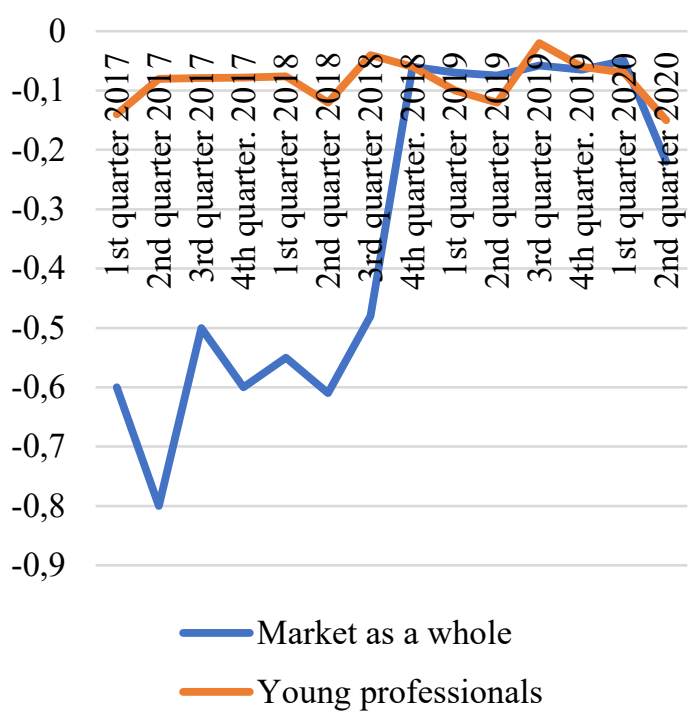

Figure 1 Index of well-being of applicants [9].

The index shows the expectations of job applicants for a given period of time and ranges from " -1 " to "+1", where "-1" indicates the negative mood of workers, "+1" - about their stable self-awareness in the labor market.

2. Distribution of respondents' answers to the question: "Do you feel that it is difficult to find a job in your professional field?"

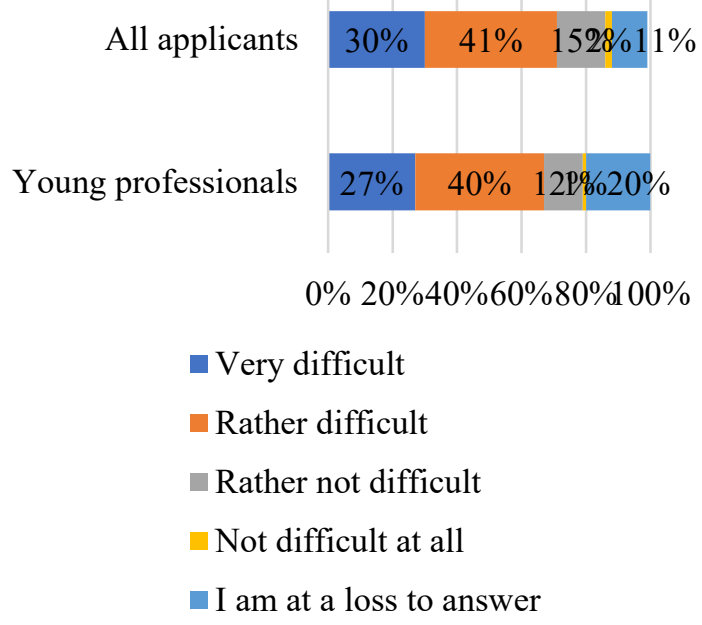

Figure 2 Distribution of answers to question No. 2 [9].

Young job applicants are pessimistic about their chances of finding a new job. Thus, the employability of the younger generation remains an important issue, which affects the well-being index of job seekers. Young specialists can be attributed to the vulnerable categories of the population, since there is no work experience, and professional knowledge requires constant reinforcement [10]. In connection with this, it is necessary to consolidate efforts between government agencies and business representatives.
4) At the Davos Forum in 2020, it was noted that the goal of companies is to involve all stakeholders in a collaborative and sustainable process of creating value. M. Porter and M. Kramer (Creating Shared Value) believe that the company's goal should be to create value for sustainable development, taking into account the interests of a wide range of stakeholders and their contribution to the increment of value $[11,12]$.

Further consideration of this issue should be related to the development of the concept of sustainable development, implemented in the corporate governance model, which should include a social focus and provide for the creation of value for all categories of stakeholders in the hotel business. It is the instability of the external environment, the threat of crises that makes it necessary to form anti-crisis management on the basis of building a model of constant cooperation of stakeholders [13]. The concept of creating shared value should include a balance of internal and external interests. The proposed methodology of values in Table 1 is not perfect, it requires additional research (using surveys, studying Russian and foreign experience in personnel management in a crisis and the transformation of the technological order):

An objective assessment of the stakeholder value that affects the sustainability of the company requires additional research. We can note some Russian and foreign scientific works that are suitable for the hotel business in the context of the implementation of anticrisis management. E. Freeman [14] notes that all business structures should be socially oriented and create, increase value for stakeholders. I.V. Ivashkovskaya suggested not just determining the contribution of stakeholders and harmonizing their interests, but also defining indices and using them to calculate the generated stakeholder value [15]. Changes in the values of stakeholders during the crisis require the construction of a new model of the personnel management system, which will effectively implement the anti-crisis strategy. In anti-crisis management, it is necessary to observe the principles in accordance with the main trends in the concept of social sustainable development:

1. Consistency - the presence of a personnel management system in the structure of strategic management of the hotel business;

2. Integrity and complexity - the effectiveness of the personnel management system depends on how competently it is built into the anti-crisis management of the organization;

3. Adaptability (urgency) and adequacy - a quick reaction of the system itself and personnel, in particular, to changes occurring at any level within the enterprise and in the external environment; 
Table 1. Subjective Stakeholder Values in a Hospitality Enterprise.

\begin{tabular}{|c|c|c|}
\hline Stakeholder categories & Values & Management tools \\
\hline Shareholders, owners & $\begin{array}{c}\text { Long-term preservation and sustainability of } \\
\text { the company }\end{array}$ & $\begin{array}{c}\text { Development strategy / anti-crisis } \\
\text { strategy }\end{array}$ \\
\hline Young professionals & $\begin{array}{c}\text { Employment, the prestige of the company, } \\
\text { the opportunity for development, favorable } \\
\text { working conditions affecting the well-being } \\
\text { in the team }\end{array}$ & $\begin{array}{c}\text { Modern systems of mentoring, } \\
\text { internships, coaching technologies, } \\
\text { etc. }\end{array}$ \\
\hline Staff & $\begin{array}{c}\text { Stability, development, career growth, } \\
\text { adaptation during digitalization of processes }\end{array}$ & $\begin{array}{c}\text { Training, pay guarantee, corporate } \\
\text { culture }\end{array}$ \\
\hline Managers & $\begin{array}{c}\text { Adequate assessment of his work, self- } \\
\text { realization, development of his own } \\
\text { competencies }\end{array}$ & $\begin{array}{c}\text { Crisis management, } \\
\text { implementation of digital products, } \\
\text { team building, delegation, tactical } \\
\text { decisions, training. }\end{array}$ \\
\hline Consumers & A unique hotel offer that meets broad needs & Experience economy \\
\hline
\end{tabular}

4. Variability - the ability of personnel to quickly rebuild in accordance with the chosen way of anti-crisis measures;

5. Optimality and efficiency - in the presence of different options and the speed of decision-making, it is necessary to be ready, have a desire to develop and expand professional skills;

6. Balance - the interests of participants in corporate governance, including personnel, must be real and achievable and not contradict the overall goal of the organization;

7. Innovativeness - the use of innovative technologies in creating a personnel management system and at the same time restructuring the work of personnel, taking into account the introduction of new technologies;

8. The combination of the rights and responsibilities of the personnel management service as the center of responsibility for the production of a quality product;

9. Correlation of personnel costs and personnel management with the practical results of the hotel business;

10. Compliance with labor laws.

\section{CONCLUSION}

Thus, the modification of the personnel management system does not fully meet the requirements of the external environment, not all socially significant problems are solved yet. In a crisis, it becomes more difficult to implement the concept of corporate sustainability, as the needs and requirements of stakeholders have also transformed. At the same time, the interaction between the public sector and business should expand in matters of training young specialists. In the course of the study, the main categories of stakeholders in the corporate management of a hotel company were identified, which ensure corporate social sustainable development in the context of the implementation of the anti-crisis strategy.
Exploring the interests of stakeholders, the corporate social sustainability of a hotel enterprise during a crisis, it becomes obvious that in the anti-crisis management model, the relevance of the transformation of the personnel management system is increasing, and the demand for awareness and responsibility of business, the state and society is growing.

\section{REFERENCES}

[1] What is sustainable development for a hotel. Hotel Report, 3 (2020). https://hotel.report/technology/cht o-takoe-ustojchivoe-razvitie-dlya-otelya.

[2] Certification program. https://certifications.controlu nion.com/ru/certification-programs/certificationprograms/gstc-global-sustainable-tourism-council.

[3] J. Elkington, Enter the Triple Bottom Line. The Triple Bottom Line: Does it All Add Up? Assessing the Sustainability of Business and CSR, 2004, pp. 116.

[4] R. Steurer, M.E. Langer, A. Konrad, A. Martinuzzi, Corporations, Stakeholders and Sustainable Development I: A Theoretical Exploration of Business Society Relations. Journal of Business Ethics, 61 (2005) pp. 263-281.

[5] G.S. Rosenberg, D. B. Gelashvili, G. P. Krasnoshchekoe, Steep steps of the transition to sustainable development. Bulletin of the Russian Academy of Sciences, 1996 pp. 436-441.

[6] T. Dyllick and K. Hockerts, Beyond the Business Case for Corporate Sustainability'. Business Srategy and the Environment, 11 (2002) pp. 130-141.

[7] GSTC Industry Criteria with performance indicators for Hotels. https:/www.gstcouncil.org/gstccriteria/gstc-industry-criteria-for-hotels/.

[8] 2nd Edition UNWTO Global Tourism Investment forum. https://www.unwto.org/2nd-edition-unwtoglobal-tourism-investment-forum. 
[9] The mood of young professionals in the labor market on the eve of the 2nd quarter of 2020. https://ekaterinburg.hh.ru/article/26791.

[10] A. Zintsoya, "Social - Professional" Safety of Young Professionals in the Course of Their Professional Adaptation. In: International Multidisciplinary Scientific Conferences on Social Sciences and Arts (SGEM 2014), Albena, Bulgaria, 2014, pp. 11-15.

[11] M.E. Porter, M.R. Kramer, (2011). Creating shared value: How to reinvent capitalism and unleash a wave of innovation and growth. Harvard Business Review, 2011 pp. 62-77.

[12] I.N. Tkachenko, Updating the stakeholder approach to corporate governance in the context of the coronavirus crisis: from declaring commitment to applied models, 12(2) (2021) pp. 2-16.

[13] I.G. Ovchinnikova, M.S. Khokholush, Conceptual framework of the personnel management system in the task of harmonizing the interests of the internal stakeholders of the organization. In: Transformation of corporate governance models in new economic realities: materials of the international scientific and practical conference, Yekaterinburg, Ural State University of Economics, 2020, pp. 101-107.

[14] R.E. Freeman, S.R. Velamuri, A new approach to CSR: Company stakeholder responsibility. Corporate Social Responsibility, 2005 pp. 9-23.

[15] I.V. Ivashkovskaya, Stakeholder Approach to Management Oriented to Increase the Company's Value. Corporate Finance, 1(21) pp. 14-23. 